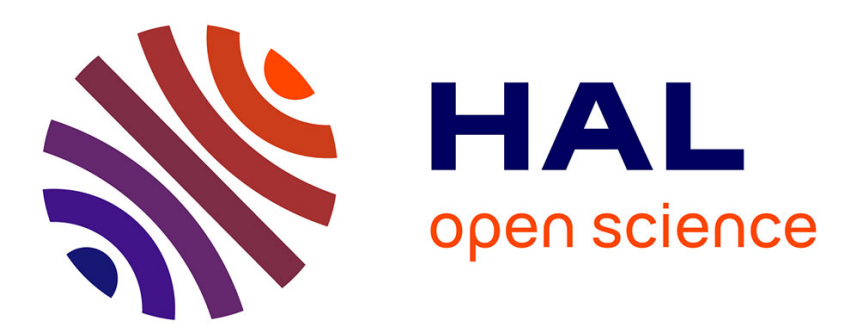

\title{
Comment on: "Floating a "lifeboat": The Banque de France and the crisis of $1889 "$ by P.C. Hautcoeur, A. Riva, and E.N. White
}

Stefano Ugolini

\section{- To cite this version:}

Stefano Ugolini. Comment on: "Floating a "lifeboat": The Banque de France and the crisis of 1889" by P.C. Hautcoeur, A. Riva, and E.N. White. Journal of Monetary Economics, 2014, 65, pp.120-123. 10.1016/j.jmoneco.2014.04.009 . hal-01293759

\section{HAL Id: hal-01293759}

https://hal-univ-tlse2.archives-ouvertes.fr/hal-01293759

Submitted on 25 Mar 2016

HAL is a multi-disciplinary open access archive for the deposit and dissemination of scientific research documents, whether they are published or not. The documents may come from teaching and research institutions in France or abroad, or from public or private research centers.
L'archive ouverte pluridisciplinaire HAL, est destinée au dépôt et à la diffusion de documents scientifiques de niveau recherche, publiés ou non, émanant des établissements d'enseignement et de recherche français ou étrangers, des laboratoires publics ou privés. 


\title{
Comment on Floating a "lifeboat": the Banque de France and the crisis of 1889 by P.C. Hautcoeur, A. Riva, and E.N. White
}

\author{
Stefano Ugolini ${ }^{\text {a,b,*1 }}$ \\ ${ }^{\text {a}}$ University of Toulouse, France \\ ${ }^{\mathrm{b}}$ LEREPS, France
}

Highlights:

- Bagehot argued that lifeboats are always suboptimal.

- Assessing systemicness is difficult.

- Too much information is required to offset undesirable distributional effects.

- Optimal lifeboats might be impossible to implement.

Keywords: Lending of last resort; Bailout; SIFI; Moral hazard; Bagehot; Banque de France; Baring crisis

JEL Classification: E58, G01, N13, N23

*Correspondence address: Toulouse Institute of Political Studies, 2ter rue des Puits-creusés, 31685 Toulouse Cedex 6, France. Tel.: +33561128703.

Email address: stefano.ugolini@ut-capitole.fr

\footnotetext{
${ }^{1}$ I thank Marvin Goodfriend for his kind invitation to contribute, as well as conference participants for the warm interest they displayed in many of the issues raised by my discussion. I also thank Suzanne Ramirez for her help in revising this text. The usual disclaimers apply.
} 
After the calamitous events of 2007-8, US regulators appear to have taken for granted that central banks" "lifeboats" of insolvent financial institutions are necessarily a bad thing. This paper argues that such an assumption might be wrong. According to the authors, it is possible to single out at least one historical episode - the 1889 bailout of Comptoir d'Escompte $(\mathrm{CdE})$ by Banque de France $(\mathrm{BdF})$ - showing that "good" lifeboats may exist. In their view, this bailout was a success because it allowed for an orderly management of the troubles of a systemically important financial institution (SIFI) while providing the right incentives to prevent the rise of moral hazard.

The authors must be praised for bringing back to our attention this very interesting episode, which is perfectly representative of the difficulties and ambiguities inherent to the evaluation of lifeboats. What do the French events of 1889 actually tell us about this kind of intervention?

\section{1) Bagehot on the Continent?}

According to Bagehot (1873), lending of last resort (LoLR) is a synonym for support to the money market, aimed at protecting the payments system. In Bagehot's view, the central bank's reaction to a crisis should merely consist of the continuation of ordinary standing-facility lending on a much grander scale (Bignon, Flandreau and Ugolini 2012). Maintaining such a stance allows the monetary authority to remain - in Giannini's (1999) words - "enemy of none but a common friend of all": as a matter of fact, providing market support along pre-established rules is a policy that is supposed to be neutral with respect to money market participants. Conversely, support to specific money market institutions is explicitly ruled out by Bagehot (1873, p. 104) on the grounds that 'any aid to a present bad bank is the surest mode of preventing the establishment of a future good bank' - meaning that bailouts always engender socially undesirable distributional effects (from the good to the 
bad). For instance, the Bank of England (BoE) really abided by Bagehotian rules in 1866 (when it supported the money market while letting Overend-Gurney fail), but not so in 1890 (when it set up a bailout of insolvent Baring Bros: Flandreau and Ugolini 2014). There is no doubt that BdF's reaction to the 1889 crisis belonged to the sort of operations Bagehot would have disapproved of.

If one is to justify resorting to a lifeboat, then, the powerful case made by Lombard Street against this type of intervention needs to be addressed specifically. First, one must show that ordinary LoLR would not be enough to prevent the default of the given institution from generating large negative externalities on the payments system. Second, one must demonstrate that the operation is designed so as to offset all obnoxious distributional effects. As we shall see, both propositions are indeed difficult to prove.

\section{2) Rescuing a Systemically Important Bank?}

Since 2008, academics and policymakers alike have struggled hard to understand what a SIFI actually is and how to recognize it. The issue is of the utmost importance, as systemicness is an argument that may be unduly brandished by interested parties lobbying for subsidies during a crisis. How can central bankers know whether a lifeboat is really indispensable in order to prevent money market dislocations? Unfortunately, no consensus has yet emerged on how to address this thorny question. To date, mainly two different approaches have been adopted. The first one focuses on destructive potential: systemicness is seen here as directly proportional to the negative externalities engendered by an eventual failure. The alternative approach focuses on replaceability: in this context, systemicness is interpreted as inversely proportional to the financial system's capability of finding substitutes to the failing institutions (Bongini and Nieri 2014). In the absence of a clear-cut methodology 
for measuring whether CdE really was a SIFI, it might be useful to try to estimate its degree of systemicness by both yardsticks.

As far as destructive potential is concerned, an obvious indicator is market capitalization. At the beginning of $1889, \mathrm{CdE}$ was France's third biggest joint-stock bank (BdF excluded) and the twelfth company by market capitalization. This may have provided the case for central bank support. In 1882, however, Union Générale (UG), France's biggest joint-stock bank (BdF excluded) and the sixth company by market capitalization, had not been deemed large enough for justifying a lifeboat. ${ }^{2}$ On that occasion, BdF had formally abided by Bagehotian principles: it had let UG go bust and provided market support by discounting eligible paper to eligible counterparties, thus preventing a meltdown of the payments system (White 2007). ${ }^{3}$ Of course, it might be possible that the long-term effects of the 1882 crisis had made central bankers change their mind about lifeboats in the meantime. As far as we know, however, BdF never regretted not having rescued UG. In any case, it seems difficult to argue that a collapse of CdE in 1889 would have had more destructive potential than that of UG in 1882, in the event of which the French payments system did not eventually collapse (except for one provincial bourse, which was closed down).

Size may not be a good indicator of systemicness, as relatively small institutions sometimes happen to play a very crucial role for money market functioning because of their irreplaceability. That was the case, for instance, of Baring Bros in 1890: the merchant bank was a major issuer of the standard money market instruments of the time (i.e. acceptances),

\footnotetext{
${ }^{2}$ I warmly thank David Le Bris for generously sharing this information from the database he has assembled. It must be acknowledged that UG's capitalization was severely inflated by the fact that nearly one-third of its equity had not actually been issued (White 2007). The fact remains, however, that in 1882 UG was remarkably bigger than any other French bank except BdF, while in 1889 the size of CdE was lesser than that of Crédit Foncier and roughly in line with that of its three main competitors (Crédit Lyonnais, Paribas, and Société Générale).

${ }^{3}$ White (2007) talks about a "bailout of the Paris bourse" by BdF after UG's crash. Unlike in 1889, however, BdF did not engage in non-statutory operations in 1882. In fact, it was a syndicate of bankers who formally bailed out the bourse; bankers were then able to refinance themselves through the central bank by originating paper eligible for discount. It would be interesting to understand why this apparently efficient solution, which did not infringe upon BdF's statutes, was not taken into consideration when the rescue of CdE was designed.
} 
and its default would have put the English payments system into disarray (Flandreau and Ugolini 2014). And in fact, the London interbank market reacted nervously to rumors about Barings' difficulties, and really panicked when the prospect of a default materialized; as soon as the BoE set up a lifeboat, however, trust recovered and interbank rates went down. ${ }^{4}$ No such signs of nervousness could be observed, on the contrary, in 1889 Paris: before and after the outburst of CdE's crisis, interbank rates remained more or less flat and well below the central bank's standing facility rate, as if nothing serious had been happening in the meantime (see below, figure 1). ${ }^{5}$ As a matter of fact, unlike Barings, CdE was not an important originator of money market instruments. In its 1888 end-of-year balance sheet, the French joint-stock bank displayed less than fr.33m outstanding acceptances out of total fr. $381 \mathrm{~m}$ liabilities. ${ }^{6}$ By contrast, in 1890, Barings’ lightly capitalized partnership had outstanding acceptances for around £15m (i.e. nearly fr.378m: Chapman 1984, p. 121): even correcting for the larger size of the London money market with respect to the Paris one, the orders of magnitude do not seem to be comparable. All this appears to suggest that CdE may not have been an irreplaceable player on the money market. ${ }^{7}$ Unlike in the case of Barings (and Lehman), troubles generated by a CdE default could perhaps have been expected to not spread all around the payments system, but to remain confined to some specific subsectors of the national financial system.

\footnotetext{
${ }^{4}$ This is the opposite of what happened with Lehman Bros: in fall 2008, interbank rates remained flat in the weeks preceding the crisis and skyrocketed afterwards. As Lehman and Barings were both SIFIs, such different patterns are probably explained by differing market expectations. In all likelihood, the bailout of Barings had not been anticipated in 1890 (as no such interventions had ever been put in place by the BoE), while that of Lehman had been incorrectly anticipated in 2008 (as a number of financial institutions had already been rescued in the preceding months).

${ }^{5}$ Note that in the $19^{\text {th }}$ century central banks typically did not implement money market operations in order to steer interbank rates (although with some exceptions: Jobst and Ugolini 2014). As a result, the spread between the interbank rate and the central bank's standing facility rate can be taken as an indicator of money market pressure (Bignon, Flandreau and Ugolini 2012).

${ }^{6}$ Le Figaro, Supplément littéraire du dimanche, February 24, 1889.

${ }^{7}$ An alternative explanation might be that the bailout of $\mathrm{CdE}$ was indeed correctly anticipated by money market participants. Besides being ungrounded by historical evidence, such an explanation would be at odds with the authors' argument that BdF was acting in order to avoid moral hazard.
} 
On the eve of its collapse, a number of contemporaries warned of the systemicness of CdE. Yet their words cannot always be taken at face value, as observers may have been either ill-informed or concerned about its destructive potential for themselves (rather than for the whole payments system). Systemicness is indeed a very good argument to be brandished in order to invoke assistance from central bankers. Understanding whether similar claims are grounded is, however, a very delicate issue. One hundred and twenty-five years after its crisis, available evidence still does not establish conclusively whether CdE really was a SIFI or not.

Figure 1 about here

\section{3) Can Moral Hazard Be Avoided?}

The possibility of being rescued by central bankers in case of crisis amounts to a sort of put option: once provided with such an option, financial institutions will expect to always receive assistance regardless of the quality of their assets. Of course, this is a considerable source of moral hazard. So then, the question is how to price the option high enough to eliminate perverse incentives. According to some (e.g. Calomiris 2011), no price would ever be really prohibitive: hence, the put should simply not exist. In contrast to this, the paper claims that a correct yet non-infinite price can be found for the put. In the authors' view, the conditions attached to BdF's lifeboat of CdE were harsh enough to offset all distributional effects. Their conclusion is that the absence of major banking shocks in France from 1890 to 1914 can be interpreted as evidence of the fact that BdF's hawkish stance towards CdE did avoid the rise of moral hazard. ${ }^{8}$

To show that misbehavior was severely sanctioned, the authors enumerate the punishments that were inflicted on the guilty. On the one hand, a number of people involved

\footnotetext{
${ }^{8}$ Of course, there might have been plenty of other reasons why France (like almost all European countries) did not experience any major domestic banking crash in the twenty-four years that preceded World War One. As the question is complex, it will be expedient not to venture into it here.
} 
in the organization of the Copper Syndicate were subjected to pecuniary and nonpecuniary sanctions. These were mainly managers and directors of CdE and Société des Métaux (SdM), like Denfert-Rochereau (who lost his life), Secrétan (who lost his freedom), Hentsch (who lost his property), Tessionnière and Baudelot (who lost their posts), etc. On the other hand, the financial institutions involved in the funding of the corner were required to guarantee a fraction of the extraordinary loans extended by $\mathrm{BdF}$ to $\mathrm{CdE}$, with a contribution proportional to their degree of involvement. While the first group paid quite dearly for their sins, the second group passed through the crisis fundamentally unscathed. Thanks to a quick recovery in the price of copper (and a little help from judges, who nullified many of CdE's engagements), the bailed-out bank was able to repay all of its debts to BdF: as a result, members of the Guarantee Syndicate never had to pull a single coin out of their pockets in order to keep CdE afloat. This seems to imply that differential prices were fixed for the put option: some paid quite dearly, some others did not. Yet, it is still conceivable that these "personalized" prices had indeed been set correctly enough to offset all distributional effects and discourage the guilty from misbehaving again. What does historical evidence tell us about this?

When CdE's troubled situation was disclosed to the general public, allegations were made in Parliament and in the press concerning the dynamics of the crisis. It was said that the Copper Syndicate formed in 1887 was not a homogeneous crowd, but the merger of two interest groups whose strategies had been conflicting up to that moment. On the one hand, there was one interest group (we shall call it "group A") who had been pursuing the plan of taking control of the demand side of the world copper market: it included SdM and its financial allies Hentsch, Paribas, and CdE. This is the network that is well visible in figure 5 of the paper. On the other hand, there was another interest group ("group B") who, on the contrary, had been trying to seize control of the supply side of the market: it included 
Rothschilds, Société Générale, and a number of British investors. This network is not at all visible in figure 5, but it played a crucial role in the story. Although in 1887 the two groups had agreed to create the Copper Syndicate, in early 1888 members of B inexplicably refused to extend the loans they had promised to SdM. According to contemporaries, this move prompted rumors, weakened the whole plan, and forced Secrétan to recapitalize SdM in difficult circumstances. Group B then came back to the scheme and contributed to SdM's recapitalization, but the situation was already compromised by then. When the crisis erupted, some members of A paid for it dearly, while members of B (some of whom were very influential in BdF) were only asked to contribute to the Guarantee Syndicate. In the long term, the crisis allowed B to seize full control of the world copper market by freeing it from A at no cost.

These allegations were labelled as conspiracy theory at the time, but historians had to take them seriously. Gille (1968, pp. 56-60) wrote that available archival evidence allowed neither to prove nor to disprove them. However, Mollier (1991, pp. 291-306) discovered additional files that would rather appear to confirm them. In fact, since the early 1880 s, members of group B had been building up a monopoly of copper mining around the world: this plan was finalized after CdE's crisis, as we know for sure that a new Copper Syndicate was successfully set up in London in 1895 (Ferguson 1999, pp. 353-4).

Although we are still unable to establish conclusively to what extent allegations corresponded to real facts, available evidence is enough for raising doubts about the neutrality of BdF's intervention to rescue CdE. In fact, we cannot rule out the possibility that, far from discouraging the guilty from repeating their sins, the lifeboat engendered substantial distributional effects in favor of a few (i.e. members of group B, who supposedly free-rode on the Copper Syndicate in order to appropriate monopoly rents). This may not have been surprising in a world where central banks were controlled by private investors and hence, 
prone to flagrant conflicts of interests. Even in a world where central bankers behave as social planners, however, designing lifeboats correctly may be an extremely difficult task. If nothing else, the above-mentioned evidence suggests that in order to assess all of the distributional effects engendered by a lifeboat, a lot of information may be required. Access to such a large amount of sensitive information may, however, often be unavailable to central bankers. Given this lack of information, setting the right price for the put option embedded in lifeboats might well be impossible.

\section{4) Sum-Up: Floating a "Lifeboat" (or Not)?}

This paper has the great merit of reviving the history of a lifeboat which, much more than other ones (e.g. BoE's 1890 rescue of Baring Bros, that actually was a SIFI), confronts us with the dramatic ambiguities inevitably connected to this kind of intervention. The events of 1889 teach us at least two very important things. Firstly, evaluating whether a financial institution really is a SIFI is a much less straightforward task than it might appear at first sight: if assessing the degree of systemicness is a very tricky exercise ex-post, it will even more be so ex-ante. Secondly, offsetting the distributional effects (conducive to moral hazard) that are inherently linked to a lifeboat is an extremely complex issue, requiring access to private information that is hardly available to central bankers. All this suggests that additional investigation on the historical record of lifeboats might be needed in order to gain more positive lessons on how to deal with them. No doubt, this will be a promising avenue for research in the future. In the meantime, keeping a prudent stance towards the desirability of such intervention may not be a bad idea after all. 


\section{References}

- Bagehot, Walter (1873), Lombard Street: A Description of the Money Market, London: King.

- Bignon, Vincent, Marc Flandreau, and Stefano Ugolini (2012), "Bagehot for Beginners: The Making of Lender-of-Last-Resort Operations in the Mid-Nineteenth Century", Economic History Review, 65:2, pp. 580-608.

- Bongini, Paola, and Laura Nieri (2014), "Identifying and Regulating Systemically Important Financial Institutions", Economic Notes, 43:1, pp. 39-62.

- Calomiris, Charles W. (2011), "Banking Crises and the Rules of the Game", in Geoffrey Wood, Terence C. Mills, and Nicholas Crafts (eds.), Monetary and Banking History: Essays in Honour of Forrest Capie, London: Routledge, pp. 88-132.

- Chapman, Stanley (1984), The Rise of Merchant Banking, London: Allen \& Unwin.

- Ferguson, Niall (1999), The House of Rothschild: The World's Banker, 1849-1999, New York: Viking.

- Flandreau, Marc, and Stefano Ugolini (2014), "The Crisis of 1866", in Nicholas Dimsdale and Anthony Hotson (eds.), British Financial Crises since 1825, Oxford: Oxford University Press.

- Giannini, Curzio (1999), "Enemy of None but a Common Friend of All"? An International Perspective on the Lender-of-Last-Resort Function, IMF Working Paper 99/10.

- Gille, Bertrand (1968), "Un épisode de l'histoire des métaux: le krach des cuivres", Revue d'histoire de la sidérurgie, 9:1, pp. 25-62.

- Jobst, Clemens, and Stefano Ugolini (2014), "The Coevolution of Money Markets and Monetary Policy, 1815-2008", working paper.

- Le Figaro, 1889.

- Mollier, Jean-Yves (1991), Le scandale de Panama, Paris: Fayard.

- The Economist, 1889-91.

- White, Eugene N. (2007), "The Crash of 1882 and the Bailout of the Paris Bourse", Cliometrica, 1:2, pp. 115-44. 


\section{Figures}

Figure 1: Spreads between interbank rates and central bank's standing facility rates during the CdE and Baring crises

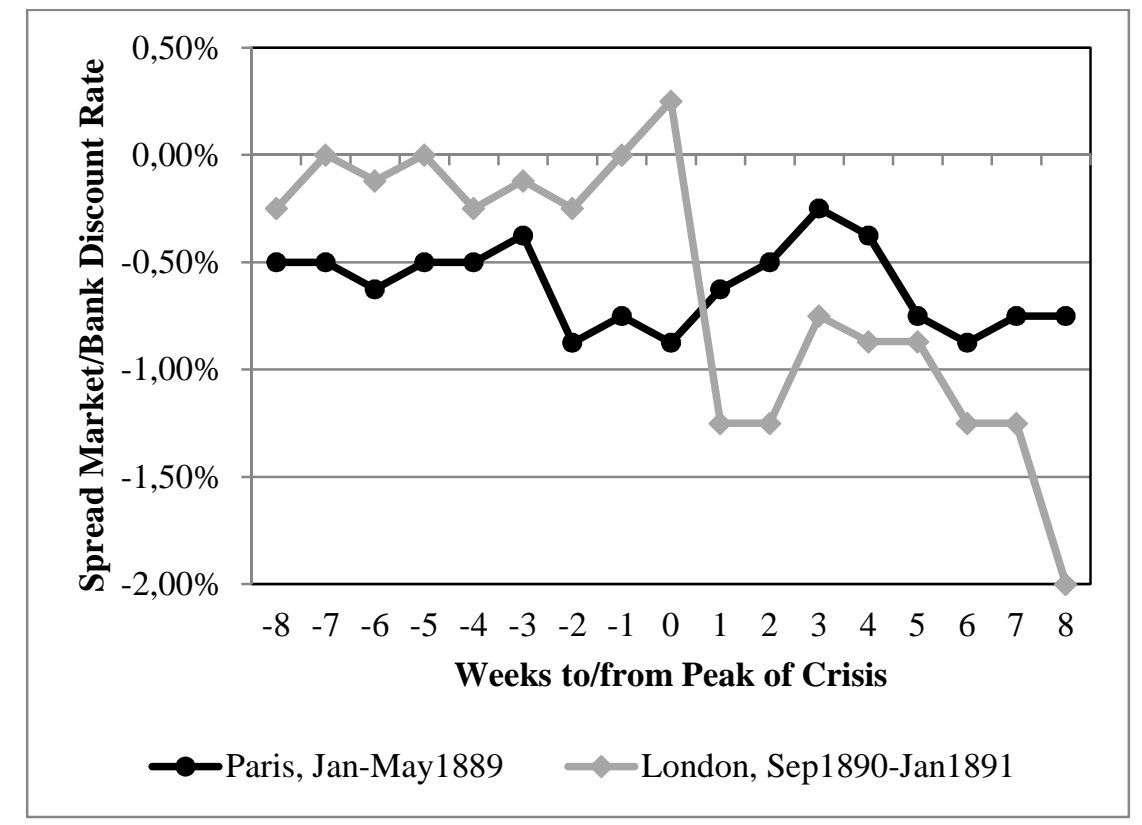

Source: Author's computations on data from The Economist (1889-1891). 